\title{
Changes of Winter Oilseed Rape Plant Survival During Vegetation
}

\author{
Oskars Balodis*, Zinta Gaile \\ Latvia University of Agriculture
}

\begin{abstract}
Winter oilseed rape (Brassica napus L.) significance among field crops is unchangeable in Latvia in the last decade. Plant density of winter oilseed rape during growth period is influenced by plant development in autumn and plant wintering. The aim of four year $(2008$ - 2011) research in the LLU Research and Study farm "Vecauce" was to investigate the influence of agronomical factors (sowing date, sowing rate, fungicide (metkonazole)) application and meteorological factors on two type (line, hybrid) winter oilseed rape varieties plant density changes from sowing till harvesting. Plant density in autumn, spring and during harvesting was influenced also by meteorological parameters such as air temperature and precipitation. On four year average, field germination was observed from $66 \%$ to $95 \%$. Sowing date significantly $(\mathrm{p}<0.05)$ impacted plant survival during winters in all trial years for both varieties - 'Californium' and 'Excalibur', except for 'Excalibur' in the year 2008. Plant survival during winter for 'Excalibur' (hybrid) was higher compared to 'Californium' (line). Higher plant losses during winter were noted on the latest sowing date for both varieties. Winter oilseed rape plant survival was not significantly $(p>0.05)$ influenced by fungicide as growth regulator application in autumn in any trial year. Influence of sowing date and sowing rate on the total plant density at harvest time was significant in all trial years $(p<0.05)$ for both varieties. At higher sowing rate the plant loss during growing period was higher than at lower rates.

Key words: wintering, sowing date and rate, fungicide as growth regulator, plant density.
\end{abstract}

\section{Introduction}

Latvia, especially the central region, has suitable soils and meteorological conditions for winter oilseed rape cultivation. The area sown with winter oilseed rape occupied 54\% in the year 2012 from the total oilseed rape sowing area in Latvia (Central Statistical Bureau of Latvia). From time to time winter conditions in Latvia are critical for oilseed rape growing because of very poor wintering in many fields. Sowing date, sowing rate (plant density) and other agronomical factors are still very important to be investigated after more than 20 years of oilseed rape growing experience in Latvia, because of the climate change.

Successful plant overwintering of rape depends on plant preparation before winter in two aspects: (1) meteorological conditions for oilseed rape growth during autumn and (2) plant condition (development and chemical composition) in autumn. These factors could be influenced by the growing practices, including used cultivar, and mentioned before agronomical factors.

Plant survival during winter and unfavourable spring is one of the key factors for successful growing of winter oilseed rape in Northern countries (including Latvia and Lithuania). Researchers in Lithuania (Butkute et al., 2006) stressed that each year meteorological conditions are significantly influencing the oilseed rape overwintering results because of different autumn conditions (temperature, precipitation) before winter. Total winter damage of winter oilseed rape is widespread experience in Estonia. Negative temperature was the most important factor for bad wintering in the year 2002/2003 in four-year (2001 - 2005) field experiments with winter oilseed rape (Laaniste et al., 2008). Still, enormous experiments and investigations have to be done in order to improve the winter oilseed rape genome for better wintering, especially frost resistance (Waalen et al., 2011).

Rape seed germination is affected by soil moisture and temperature (Kondra et al., 1983; Rapacz and Janowiak, 1998, Diepenbrock, 2000). Dry and cold seedbed will result in reduced and delayed germination, reduced rate of seedling emergence and may inhibit germination altogether until rain occurs (Rapacz, 1998). Also, water is essential for plant growth. The amounts and duration of rainfall cannot be controlled and may be a limiting factor for crop growth unless irrigation is applied, as too much or too less water at any particular growth stage reduces yield potential (Good and Maclagan, 1993).

Moisture availability and temperature period can affect oilseed rape plant development and plant density in autumn. Results in Lithuania show that the best overwintering of winter oilseed rape occurred with plant density from 30 to 60 plants $\mathrm{m}^{-2}$ (Velicka, 2003). Still good wintering (75\% survived) is observed also at high plant density $\left(90\right.$ plants $\left.\mathrm{m}^{-2}\right)$

\footnotetext{
* Corresponding Author's email: balodis.oskars@inbox.lv
} 
(Velicka et al., 2005). The first decade of August in Estonia (Laaniste et al., 2008) and the last decade of August in the middle part of Lithuania (Velicka et al., 2012) are the most appropriate for good winter oilseed rape overwintering. Overly high plant density in oilseed rape decreases possibility of plants to survive through winter - only $20 \%$ plant survival at density of 120 plants $\mathrm{m}^{-2}$ before winter observed in the UK (Leach et al., 1999).

Fungicides application in autumn for winter oilseed rape fields is widespread practice in Latvia. The aim of application is oriented on plant growth regulation, less to limit disease incidence. Also, trial results demonstrated the benefit of fungicide application on wintering results and seed yield. Fungicide (azole group) application in autumn affected plant biometrical parameters and increased seed yield up to $0.43 \mathrm{tha}^{-1}$ if compared with untreated plants (Balodis et al., 2007).

The aim of currently described section of our research was to investigate the influence of agronomical factors (sowing date, sowing rate, fungicide (metkonazole)) application and meteorological factors on two type winter oilseed rape cultivars plant density changes from sowing till harvesting.

\section{Materials and Methods}

The investigations were carried out with winter oilseed rape (Brassica napus ssp. oleifera) plants. To achieve the defined aim, four-year (starting from $2007 / 2008$ to $2010 / 2011$ ) experiments were carried out at the Research and Study farm "Vecauce" (latitude: N $56^{\circ} 28^{\prime}$, longitude: E $22^{\circ} 53^{\prime}$ ) of Latvia University of Agriculture. Three-factor field trial in four replications was established for two type winter oilseed rape varieties (open pollinated 'Californium' and hybrid 'Excalibur', both bread by Monsanto Crop Science - DEKALB). The paper is focused on plant density results in all trial years. The following factors were investigated:

Factor A - five sowing dates:

1) 1 August (2 August 2007; 1 August 2008; 31 July 2009; 2 August 2010),

2) 10 August (10 August 2007, 2009, 2010; 11 August 2008),

3) 20 August (20 August 2007, 2009; 21 August 2008; 22 August 2010),

4) 1 September (31 August 2007, 2010; 30 August 2008; 2 September 2010),

5) 10 September (10 September 2007, 2009; 9 September 2008, 2010).

Factor B - sowing rate: $(\mathrm{B} 1$ - 120, B2 - 100, B3 - 80, B4 - 60 germinate able seeds per $\mathrm{m}^{2}$ - 'Californium'; B1 - 80, B2 - 60, B3 - 40, B4 -
20 germinate able seeds per $\mathrm{m}^{2}$ - 'Excalibur' in 2007/2008 and in 2010/2011.

Factor $\mathbf{C}$ - fungicide application $(\mathrm{C} 1$ - control, without fungicide; $\mathrm{C} 2$ - fungicide applied as growth regulator). Fungicide application scheme: $0.5 \mathrm{~L} \mathrm{ha}^{-1}$ of fungicide Juventus 90 s.c. (metconazole, $90 \mathrm{~g} \mathrm{~L}^{-1}$ ) was applied at the $4-6$ leaves stage (GS $14-16$ $\mathrm{BBCH}$ ) on oilseed rape sown on 1 August, 10 August and 20 August:

- on plants sown on 1 August (exactly 30 August 2007; 8 September 2008, 2009; 9 September 2010);

- on plants sown on 10 August (2 September 2007; 13 September 2008; 22 September 2009; 24 September 2010);

- on plants sown on 20 August (27 September 2007; 8 October 2008; 30 September 2009; 7 October 2010.

Soil type (by World Reference Base for Soil Resources) at trials' site was Stagnic Phaeozem (Endocalcaric) in the years 2008 and 2009, Stagnic Cambisol (Endocalcaric, Hypereutric, Novic) in 2010, Luvic Ednostagnic Phaeozem (Protoanthric, Calcaric) in 2011. Soil agro-chemical parameters were slightly different depending on a year (Table 1), but conditions were suitable for winter oilseed rape growing.

Table 1

Soil parameters at trial site depending on year

\begin{tabular}{lcccc}
\hline & \multicolumn{4}{c}{ Year } \\
\cline { 2 - 5 } Parameter & 2008 & 2009 & 2010 & 2011 \\
\hline $\begin{array}{l}\text { Soil exchange } \\
\text { reaction pH KCl }\end{array}$ & 7.4 & 7.2 & 7.2 & 6.7 \\
\hline $\begin{array}{l}\text { Plant - usable K, } \\
\text { mg kg-1 (by Egner - }\end{array}$ & 194 & 169 & 141 & 104 \\
$\begin{array}{l}\text { Rheem method) } \\
\text { Plant - usable P, } \\
\text { mg kg-1 (by Egner } \\
- \text { Rheem method) }\end{array}$ & 115 & 100 & 111 & 111 \\
\hline $\begin{array}{l}\text { Organic matter, g kg-1 } \\
\text { of soil (by Tiurin } \\
\text { method) }\end{array}$ & 38 & 30 & 22 & 27 \\
\hline
\end{tabular}

Pre - crop was cereal mixture for silage in all trial years. Herbicide Raundap Gold s.c. (glyphosate, $450 \mathrm{~g} \mathrm{~L}^{-1}$ ), 3.0 $\mathrm{L} \mathrm{ha}^{-1}$, was applied two weeks before traditional soil tillage with mould-board ploughing. Rototilling was performed before sowing. Sowing was done close (with one or two days deviation) to established dates; deviations in some occasions 


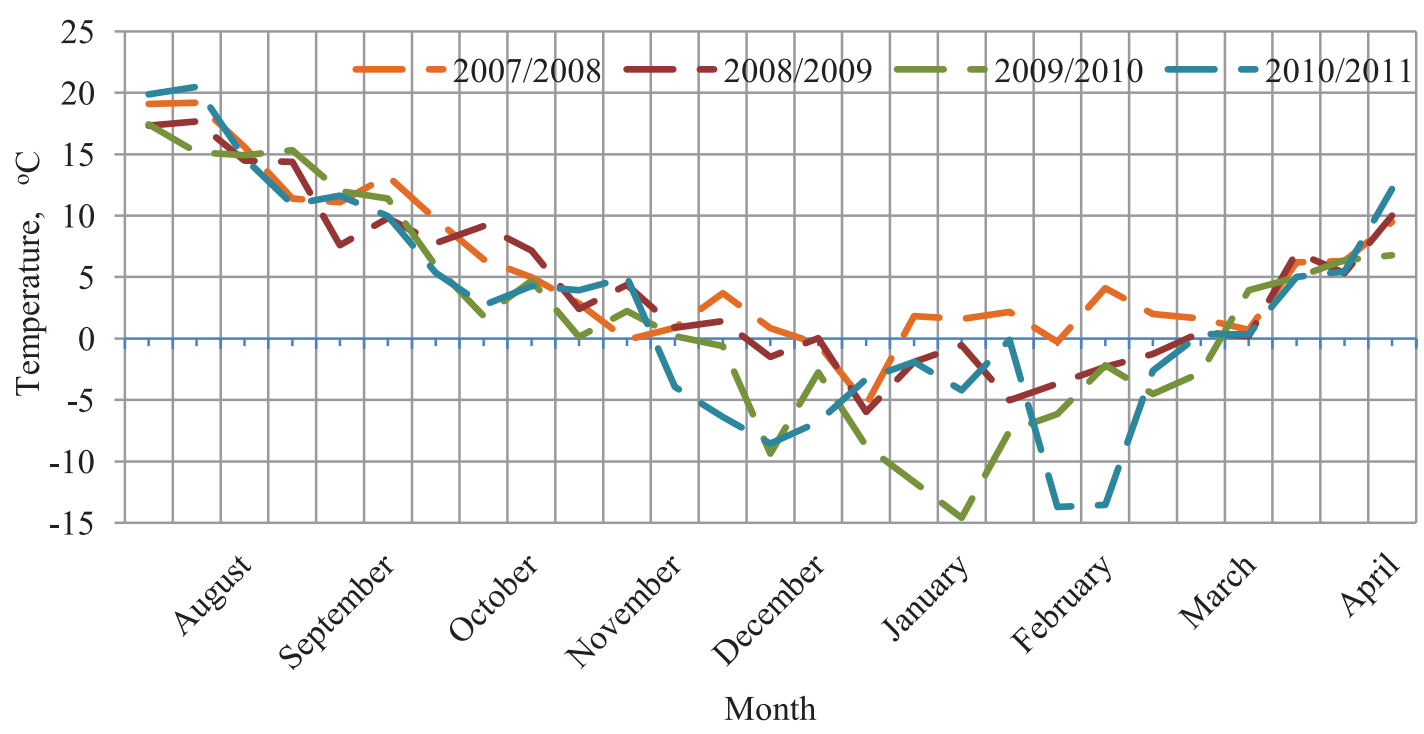

Figure 1. The mean air temperature of each decade of month during overwintering.

occurred because of inappropriate (mainly overly moist) soil conditions for sowing. The crop was fertilized with a complex mineral fertilizer at the rate of $\mathrm{N} 12$ to $28 \mathrm{~kg} \mathrm{ha}^{-1}, \mathrm{P} 18$ to $30 \mathrm{~kg} \mathrm{ha}^{-1}$, and $\mathrm{K} 79$ to $103 \mathrm{~kg} \mathrm{ha}^{-1}$ before sowing depending on a year and soil properties. Top-dressing with nitrogen fertilizer at the rate of $70 \mathrm{~kg} \mathrm{ha}^{-1}$ of $\mathrm{N}\left(\mathrm{NH}_{4} \mathrm{NO}_{3}\right)$ - at the start of vegetation, plus $70 \mathrm{~kg} \mathrm{ha}^{-1}$ of $\mathrm{N}\left(\left(\mathrm{NH}_{4}\right)_{2} \mathrm{SO}_{4}\right)$ - at the stage of well - developed rosette (GS 30), was applied. Weeds were controlled by using herbicide Butisan Star s.c. (metasachlor, $333 \mathrm{~g} \mathrm{~L}^{-1}+$ kvinmerac, $83 \mathrm{~g} \mathrm{~L}^{-1}$ ), $2.5 \mathrm{~L} \mathrm{ha}^{-1}$ in $2007-2009$, and $3.0 \mathrm{~L} \mathrm{ha}^{-1}$ in autumn 2010. Herbicide was applied when the oilseed rape was fully germinated in plots of first three sowing dates in 2007 and 2008, and directly after sowing in 2009 and 2010 for all trial. For plots sown on 1 September and 10 September, herbicide was not used in the autumn 2007 (Lontrel 300 s.c. (clopiralid, $300 \mathrm{~g} \mathrm{~L}^{-1}$ ) $0.5 \mathrm{~L} \mathrm{ha}^{-1}$ was used in the spring 2008). To decrease the possible impact of Sclerotinia stem rot (Sclerotinia sclerotiorum) incidence, fungicide Cantus d.g. (boscalid, $500 \mathrm{~g} \mathrm{~kg}^{-1}$ ) $0.5 \mathrm{~kg} \mathrm{ha}^{-1}$ was used during full flowering (GS 65).

Rape plant density was determined by counting plants in autumn after full emergence, in spring after renewal of vegetative growth, and exactly after harvesting in one constant $0.5 \mathrm{~m}^{2}$ area of each plot. Overwintering was evaluated by calculating the percentage of survived plants from those counted in autumn.

Analysis of variance (ANOVA) was used to determine differences between factors. Significance was estimated for the 0.05 probability level.
Correlation analysis was used to examine the relationship between tested factors.

As winter oilseed rape was sown with 10 days interval, the period from germination till the end of autumn vegetation was in different length for each sowing date. This means that overwintering for rape with different sowing dates started at different stages of plant development. During the trial years, meteorological conditions in the autumn and winter period differed considerably (Figure 1).

Air temperature in September and October is more important than in previous months when precipitations are playing the main role for successful plant development. October 2009 and 2010 was characterized by very low mean air temperatures. August 2009 and September 2008 were relatively dry, but August 2010 was extremely wet, the impact of precipitations of autumn plant development is explained in other paper (Balodis and Gaile, 2011). Lack of precipitations in May was observed in years 2008 and 2009; however, the growth and development of crop occurred without irregularities. Amount of precipitation in June was close to longterm observations $(51 \mathrm{~mm})$ with much higher precipitation in the year 2009. Precipitations in July in three out of four trial years were much higher than long-term observations $(75 \mathrm{~mm})$. September 2007 characterizes with very high mean air temperatures $\left(13.9^{\circ} \mathrm{C}\right.$ in the $3^{\text {rd }}$ decade) that were very suitable for plant development, but in 2008 temperatures in the middle of September were very low $\left(7.6^{\circ} \mathrm{C}\right)$. October 2009 and 2010 characterizes with very low mean air temperatures in all decades $\left(1.8\right.$ and $2.7{ }^{\circ} \mathrm{C}$ in $2^{\text {nd }}$ 
decade respectively). August 2009 and September 2008 was relatively dry, but August 2010 was extremely wet. Vegetative period (mean temperature below $5{ }^{\circ} \mathrm{C}$ for at least 3 days) ended on 4 November 2007; and 2008 and renewed for eight to five days period up to 4 December; 1 November, 2009; (twoweek period in the middle of the October registered with very low temperatures); on 7 November 2010.

Totally all winter months in 2007/2008 characterises with mildest temperatures in all trial years that influenced very successful plant overwintering. The beginning of January was coldest in that winter (only $-5.4{ }^{\circ} \mathrm{C}$ in the $1^{\text {st }}$ decade). Mean air temperatures up to the spring were above zero degrees. Frosts and particular temperature fluctuations that can damage plant growth in spring were not observed in all trial years.

Winter 2008/2009 characterises with lower temperatures than in previous winter. Mean temperatures in the beginning of December and January were the lowest (-6.0 and -5.0 respectively). Mean negative temperatures without fluctuating up to higher temperatures caused stable winter with the possibility for snow to accumulate on the ground in January, February and up to the $1^{\text {st }}$ decade of March. Pools were observed in plots sown on 1 and 10 August, which influenced plant survival during winter.

Much harsher winters were following in the next trial years (Figure1). October 2009 and 2010 characterizes with very low mean air temperatures $\left(1.8^{\circ} \mathrm{C}\right.$ in $2^{\text {nd }}$ decade and $2.7^{\circ} \mathrm{C}$ respectively).

Stabile negative mean air temperatures in winter $2009 / 2010$ were observed from the $1^{\text {st }}$ decade in December $\left(-0.6^{\circ} \mathrm{C}\right)$ even up to the $2^{\text {nd }}$ decade of March $\left(-2.8^{\circ} \mathrm{C}\right)$. Extremely low temperatures were observed in the last decade of January (mean temperature -14.6 ${ }^{\circ} \mathrm{C}$ in a decade, the lowest mean temperature on 24 February $\left(-20.0^{\circ} \mathrm{C}\right)$. Winter conditions were suitable for accumulation of stable and relatively thick snow cover (above $35 \mathrm{~cm}$, measured by the author). A very rapid air temperature increase was observed at the end of March $\left(3.9{ }^{\circ} \mathrm{C}\right.$ in $3^{\text {rd }}$ decade) that resulted in fast snow melting. Too moist soil conditions combined with relatively high air temperatures in spring caused poor survival for larger plants.

In the last trial year 2010/2011 winter started already at the end of November $\left(-4.0{ }^{\circ} \mathrm{C}\right.$, Figure 1$)$. Milder temperatures were observed in the first decade of January $\left(-1.9^{\circ} \mathrm{C}\right)$ and February $\left(-0.1^{\circ} \mathrm{C}\right)$ that caused snow cover decrease. Very cold conditions were observed in February when mean air temperatures below $-10{ }^{\circ} \mathrm{C}$ lasted for 14 days. Those temperatures possibly caused loss of poorly developed oilseed rape plants.

\section{Results and Discussion}

Oilseed rape germination and development during autumn

Four - year trial results demonstrated the importance of soil moisture and productive precipitation for successful field germination of seed. Soil moisture for good seed emergence is critical in the beginning of August, because of typically hot and dry weather conditions at the end of July in Latvia. Average field germination was lower in plots sown on 1 August in all trial years, poor field germination was observed in the year 2008 (only 67\%, Figure 2) when productive rain $(11.8 \mathrm{~mm})$ was observed only on 20 July, next rain was observed on 2 August $(2.2 \mathrm{~mm}$ ). Plants were germinated much better on the second sowing date - 10 August, high field germination $105 \%$ (possible because of technical inaccuracy of the sowing machine or germination of seeds were higher as shown on seed certificate) was observed in the year 2008, probably because of appropriate soil moister and temperatures. The lowest germination $88 \%$ was observed in the year 2010 (Fig. 2), because of dry soil conditions and plots obtained productive rain late $(29.0 \mathrm{~mm})$ only on 16 August. Good seed germination was observed when seeds were sown in the beginning of September, even up to $100 \%$ that could be the result of excellent seedbed quality, soil moisture, but in addition the reason could be inaccurate germination test result in laboratory in combination with some technical inaccuracy of the sowing machine especially in the year 2008. Also, researches in Germany show that percentage germination of rapeseed in a standard test is correlating poorly with field performance (Diepenbrock, 2000). Very poor seed germination for plots sown on 1 September was observed in the year 2007, despite sufficient moisture in soil. Results showed that sowing oilseed rape late (10 September) field germination showed extremely low values in years 2008 and 2010 (48\% and 45\% respectively), mainly because of low temperatures during germination. On four-year average, field germination was observed from 66\% (1 September) to $95 \%$ (10 August). However, there are no data about optimal field germination in winter oilseed rape fields in Latvia conditions. Experience of agronomists and private observations shows that field germination of field crops up to $70 \%$ is acceptable as a good result. As trial results affirm, oilseed rape emergence on field conditions (field germination) depends on available moisture for seed, soil temperature and the seedbed quality. Kondra et al. (1983) found that seed germination of rape seed at different temperatures varies a little, which highlights the importance of moisture in soil for seed germination. 


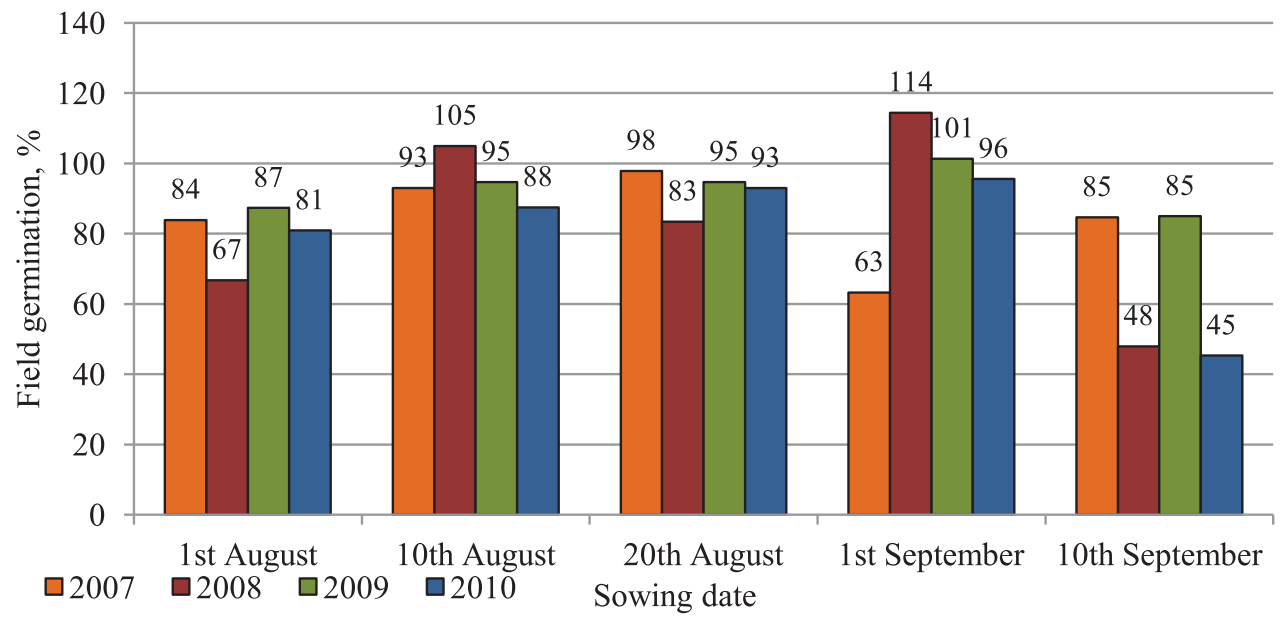

Figure 2. Average (per all sowing rates and both cultivars) winter oilseed rape field germination depending on the sowing date in 2007/2008, 2008/2009, 2009/2010, 2010/2011, \% from sown germinable seeds.

Differences in plant growth stage at the end of vegetation period depending on sowing date can significantly affect wintering. Plants sown on 1 August had 8 leaves - well-developed rosette, but plants sown on 1 September - 5 leaves but plants sown on 10 September only 4 leaves. Plant leave number (leaf area even more important) is also a parameter that influences plant survival during winter and also effects seed yield (because of more plant branching). Plant stage GS (14-16) was achieved at different time (see fungicide application dates, chapter Materials and Methods) and it depended on temperature, which plants could accumulate. Depending on autumn meteorological conditions for successful plant growth, only in the year 2007 fungicide untreated plants showed a tendency to overgrow because of inappropriate plant biometrical parameters.

Survival of plants during winter

Winter oilseed rape survival of plants through the winter or wintering is the most important characteristics for the cultivars used in such conditions as in Latvia. A four-year field experiment showed that plant survival during winter was affected by all the evaluated factors. Significant impact $(p<0.05)$ of sowing date was observed on the plant survival results in all trial years for both cultivars 'Californium' and 'Excalibur'. An exception was 'Excalibur' in the year $2008(\mathrm{p}=0.061)$ probably because of a very mild winter in 2007/2008 (Figure 1). As winters 2007/2008 and 2008/2009 were characterized with mild temperatures and sufficient snow cover (estimated only visually), plant survival of both varieties was satisfactory (lowest wintering for 'Californium' $-43 \%$ at plots and for 'Excalibur'
52\% sown on 1 August after winter 2008/2009) (Figures 3, 4). However, plants sown on 1August during the autumn 2008 were well developed and prepared (not overgrown) for wintering and that clearly gives an evidence for a huge impact on plant survival during winter of pools, which were observed in plots sown on 1 August and 10 August. There were no significant differences depending on sowing dates 1 August, 20 August and 1 September of plant survival for 'Californium' in the year 2008. Also, there were no differences on plant survival for plots sown on 10 August and 10 September (Figure 3 ). Different wintering results were obtained after the winter 2008/2009 compared with results after the winter 2007/2008. Plant survival results for 'Californium' were significantly different depending on all sowing dates, still significant differences were not observed between sowing dates on 20 August and 10 September (Figure 3). For 'Excalibur' significant differences of plant survival were not observed depending on sowing dates on 20 August, 1 and 10 September, 1 and 10 August in the year 2008/2009 (Figure 4). Plant survival results were worse after the winter 2009/2010, better plant survival results were observed on sowing date 10 August for 'Californium' - 57\% and significantly higher than on other sowing dates (Figure 3) and on 20 August - 59\% for 'Excalibur' (Figure 4). For 'Californium' there were no significant differences on wintering between sowing dates on 1August, 10 August and 1 September in the year 2010/2011. (Figure 2). For 'Excalibur' there were no significant differences on plant survival results rape sown on sowing dates 10 August, 20 August and 1 September and between 


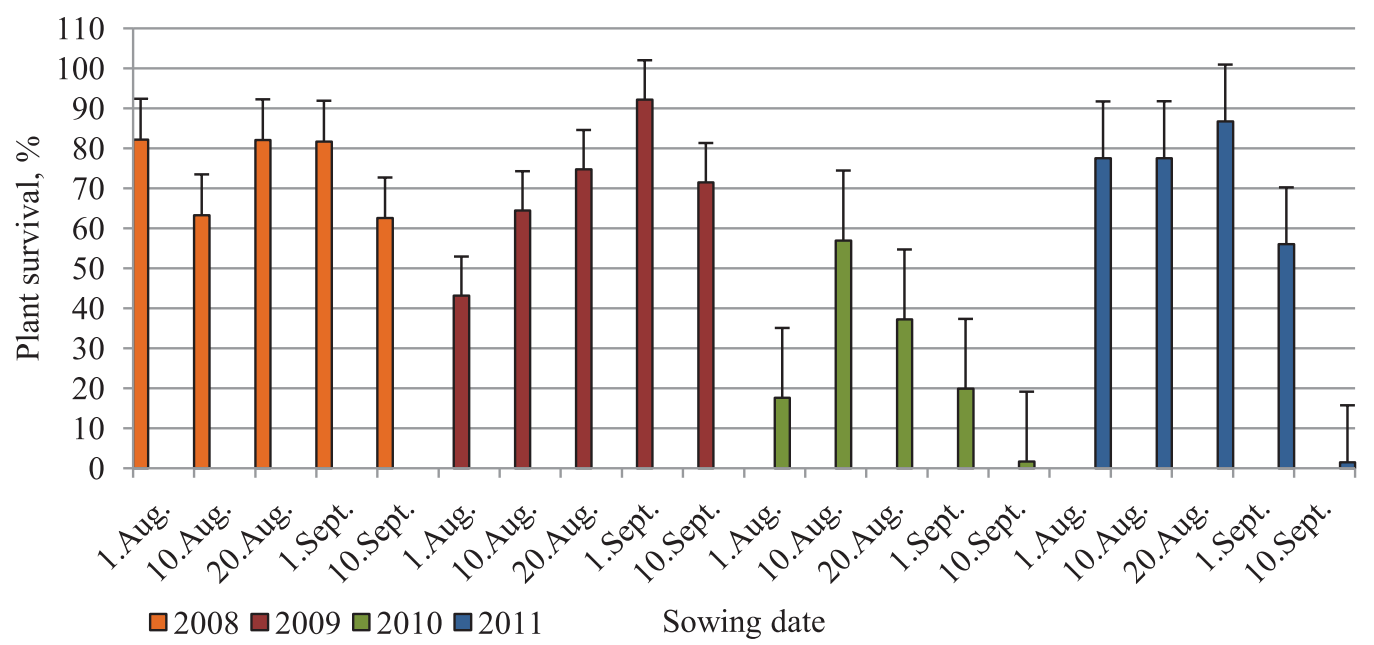

Figure 3. The effect of sowing date on winter oilseed rape plant survival for cultivar 'Californium' in the years 2008-2011 ( $\mathrm{p}<0.05)$.

sowing dates 1 August and 10 September in the year 2010 (Figure 4). Such worse plant survival results for early sown plants - larger plants could be because of too moist soil conditions combined with relatively high air temperatures in spring, which caused poor survival for both varieties. Also, plants sown on 10 September overwintering was significantly lower for both varieties especially for 'Californium' where wintering was observed only $2 \%$, probably because low temperatures during winter combined with poorly developed plants. From all trial years harsher conditions (lowest temperatures) for winter oilseed wintering was in the winter 2010/2011, however plant survival results for well-developed plants were better than after the winter 2009/2010. Higher wintering results were observed for 'Californium' $-87 \%$ and for 'Excalibur' - 93\% for plots sown on 20 August. There were no significant differences on plant survival results for plots sown on sowing dates 1 August, 10 August and 20 August for 'Californium' (Figure 3). For 'Excalibur' no differences on wintering were observed between sowing dates 1 August, 10 August and 10 September also between 10 August and 20August (Figure 4.). Only some plants survived in plots sown on 10 September for both varieties (wintering - 1\% for 'Californium' and $4 \%$ for 'Excalibur') and further investigations were discontinued in these plots.

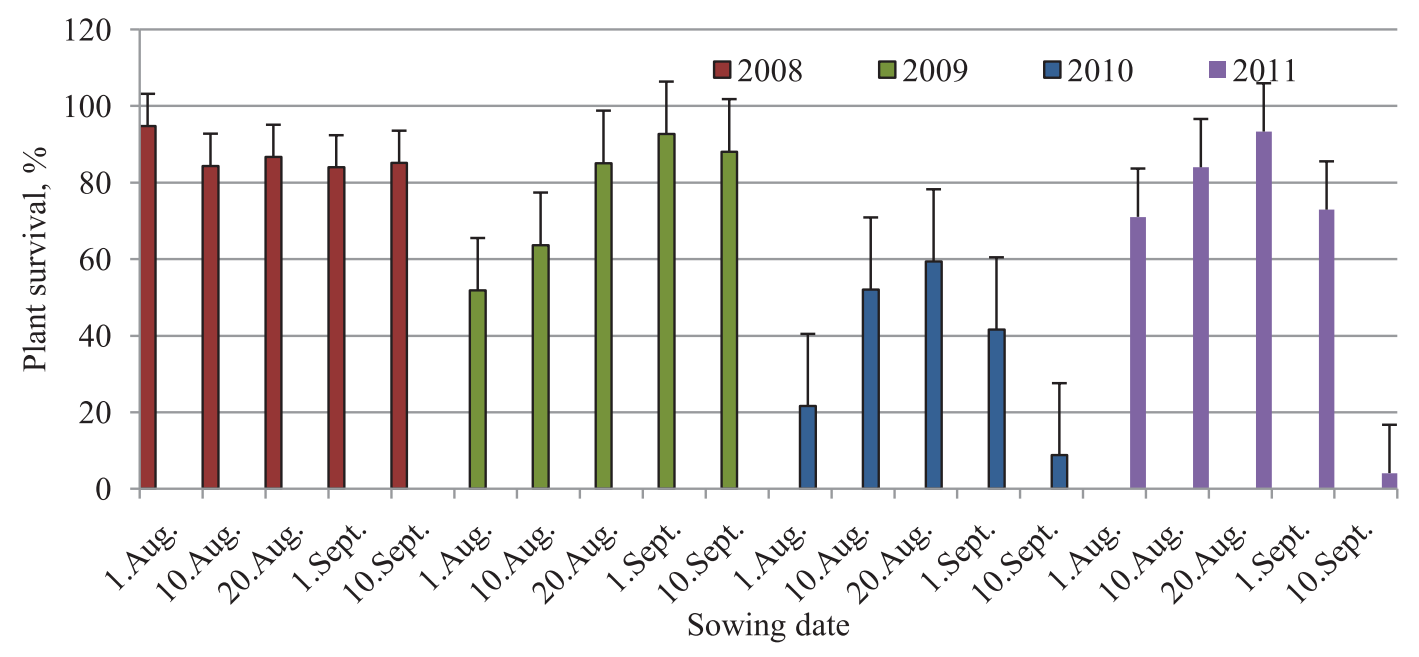

Figure 4. The effect of sowing date on winter oilseed rape plant survival for cultivar 'Excalibur' in the years 2008-2011 ( $\mathrm{p}<0.05)$. 


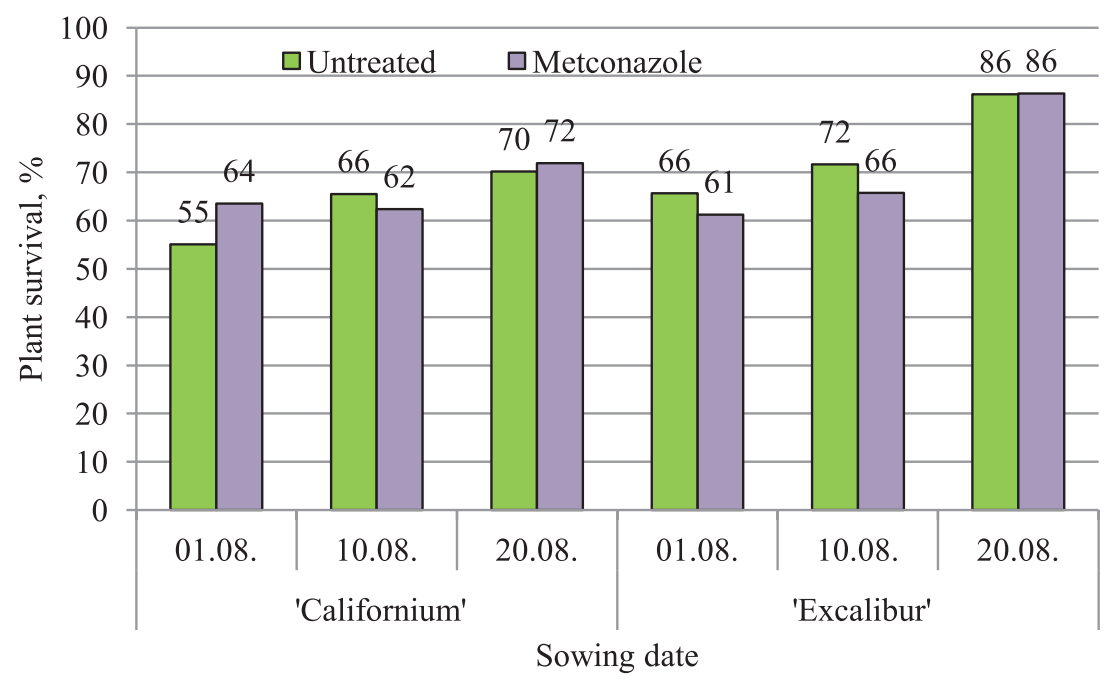

Figure 5. The impact of fungicide (metconazole $90 \mathrm{~g} \mathrm{~L}^{-1}, 0.5 \mathrm{~L} \mathrm{ha}^{-1}$ at GS 14-16) application on the oilseed rape wintering during winters 2007/2008 to 2010/2011, (p>0.05).

Average plant survival results for 'Excalibur' (hybrid) were higher, probably because of more appropriate plant biometrical parameters compared with 'Californium' (line) (Balodis and Gaile, 2011). Similar results for both varieties were obtained when the worst wintering was noted on the latest sowing date (10 September) (Figigures 3, 4). It is important to note that oilseed rape plants of 'Californium' did not survive sown on 10 September (plant survival 2\%) through the winter 2009/2010 and also after winter in 2010/2011 both cultivars did not survive sown on 10 September (Figures 3, 4).

The latest sowing (end of August) dates in Lithuania were inappropriate for plant development in autumn and that caused high number of not overwintered oilseed rape plants in spring, however early sowings (23 July - 1 August) overwintered quite poorly because of plant overgrowing in autumn (Butkute et al., 2006). In our experiments sowing date on 20 August was the most appropriate for oilseed rape plant survival (on average $70 \%$ plant survived for 'Californium' and 86\% for 'Excalibur', Figures 3, 4). The tendency that plant survival results decrease by increasing sowing rate was noted for 'Excalibur', particularly in the earliest sowing date (1 August), also the best plant survival (average from the year 2008 to $2011-79 \%$ ) in all sowing dates were observed on sowing rate 20 seeds per $1 \mathrm{~m}^{2}$. Lithuanian researcher R. Velicka states survival of plants over $50 \%$ as stable wintering. Our data are similar to Lithuanian data, where oilseed rape sown later than on 25 August has inappropriate wintering - less than $40 \%$ (Velicka, 2003). On average in all trial years the last sowing date (10 September) showed inappropriate plant survival results (less than 50\%), yet hybrid 'Excalibur' demonstrated better overwintering than open pollinated 'Californium' (47\% and 34\% respectively). Our results agree with results in Kaunas region in Lithuania where a slightly delayed sowing date revealed the hybrid variety plants ability to prepare better for wintering than line cultivar plants. Authors note that results of overwintering might have been influenced by chemical composition of plants, namely the lowest dry matter and total sugar content and the highest nitrogen to potassium ratio at the end of the renewed growth in autumn (Velicka et al., 2012).

Plant growth regulator application effect on plant survival.

The most frequent argument for growth regulator application on oilseed rape plants in autumn is the improvement of plant survival. Our four - year field experiment clearly showed that winter oilseed rape plant survival was not significantly $(p>0.05)$ influenced by fungicide as growth regulator application in autumn in any trial years. On average (all trial years, sowing rates 120, 100, 80, 60 seeds for 'Californium' and 80, 60, 40, 20 seeds for 'Excalibur') the tendency of plant survival increasing by growth regulator application was observed only for 'Californium' on sowing dates 1 August and 20 August, also no application effect was noted for 'Excalibur' (Figure 5).

As fungicide (Juventus 90) application influences oilseed rape biometrical parameters, plant chemical content and autumn growth to improve plant wintering, plant loss during winter has to be less than that of untreated plants. Fungicide as growth 


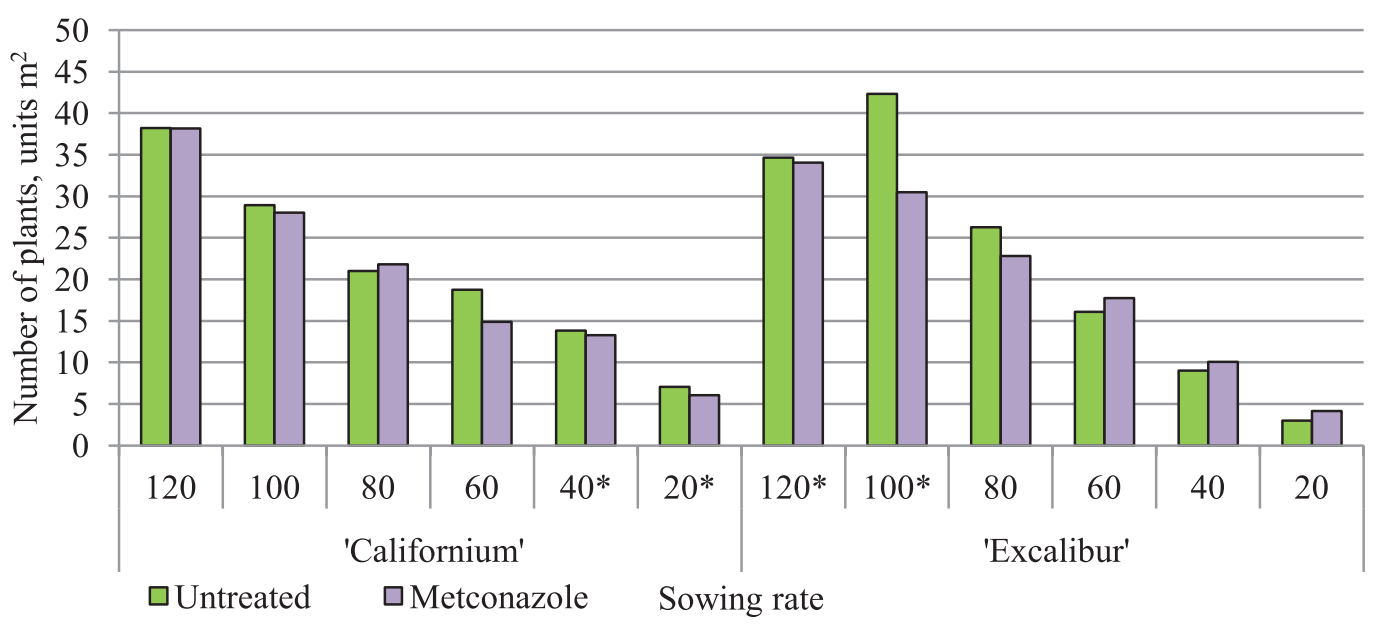

Figure 6. The impact of fungicide (metconazole $90 \mathrm{~g} \mathrm{~L}^{-1}, 0.5 \mathrm{~L} \mathrm{ha}^{-1}$ at GS 14-16) application on the average number of dead plants on three sowing dates (1,10 and 20 August) during winters 2007/2008 to 2010/2011

$$
\text { ('*' - winters 2009/2010 and 2010/2011). }
$$

regulator application in autumn improved oilseed rape plant vitality during winter and in the subsequent spring. The tendency was observed that fungicide application affected plant survival more in plots with greater plant density; an exception was 'Californium' with the sowing rate of 80 germinable seeds per $\mathrm{m}^{2}$ (Figure 6). There was no positive effect decreasing dead plant number by fungicide application after winter for 'Excalibur' when lower sowing rates (60 to 20 germinable seeds per $1 \mathrm{~m}^{2}$ ) were used. Possibility to improve oilseed rape wintering by using any growth regulation in autumn is poorly documented in Latvia. In Lithuania, some references in the literature (Gaveliene et al., 2005) show that the use of growth regulators (auxin analogues) can improve wintering of winter oilseed rape. Also, our previous study results showed that fungicide as growth regulator (metconazole and tebuconazole) treatment affected positively oilseed rape wintering results, which was evaluated in points $\left(1^{\text {st }}\right.$ approach of wintering evaluation) in some winters (Balodis et al., 2008). Average four-year trial results showed positive impact of growth regulator application on plant wintering only in some cases. Plant growth regulator (metconazole and tebuconazole) application in autumn was needed because of plant biometrical parameter changes for better plant overwintering (Šimka et al., 2011). In Canada, plant treatment in autumn with tebuconazole increased plant survival up to $48 \%$ and it was only $11 \%$ for control (Morrison and Andrews, 1992).

Oilseed rape plant density at harvest time

The main goal for winter oilseed rape establishment is sufficient total plant density at harvest time for high winter rape seed yields considering the field germination, plant losses during winter and up to harvest time. Hence, in spite of other meteorological and agronomical factors, winter rape yield can be affected also by the used sowing rate. Results showed that plant number at harvest was different according to sowing date. A tendency was noted that average plant density more decreased at earliest and latest sowing dates. It was found that influence of sowing date and sowing rate on the total plant density at harvest time was significant in all trial years $(\mathrm{p}<0.05)$ for both cultivars. It was evident that winter oilseed rape plant density at harvest (average from 2008 - 2011) was much lower in plots sown on 1 August (early sowing) if compared to plots sown on 10 August and 20 August (Figure 7 and 8). At least 30 plants after winter were sufficient for good seed yields in Lithuania conditions (marked with a black line in Fig. 7 and Fig. 8) (Velicka et al., 2012), still there is no optimal plant density determined in Latvian agroecological conditions. The highest plant density for 'Californium' at particular sowing rate was observed on 10 August sown plots (76 plants at sowing rate 120 germinable seeds per $\mathrm{m}^{2}, 60$ plants at rate 100 seeds per $\mathrm{m}^{2}, 37$ plants at rate 60 seeds per $\mathrm{m}^{2}$ ), excepted at sowing rate 80 seeds per $\mathrm{m}^{2}$ where 52 plants per $\mathrm{m}^{2}$ at harvest was noted on 20 August sown oilseed rape (Figure 7).

The highest plant density for 'Excalibur' (average from 2008 - 2011) at harvest was observed on plots sown on 20 August (64 plants at sowing rate 80 germinable seeds per $\mathrm{m}^{2}, 45$ plants at sowing rate 60 seeds per $\mathrm{m}^{2}, 30$ plants at sowing rate 40 seeds per $\mathrm{m}^{2}$ ) except 20 seeds per $\mathrm{m}^{2}$ where 17 plants 


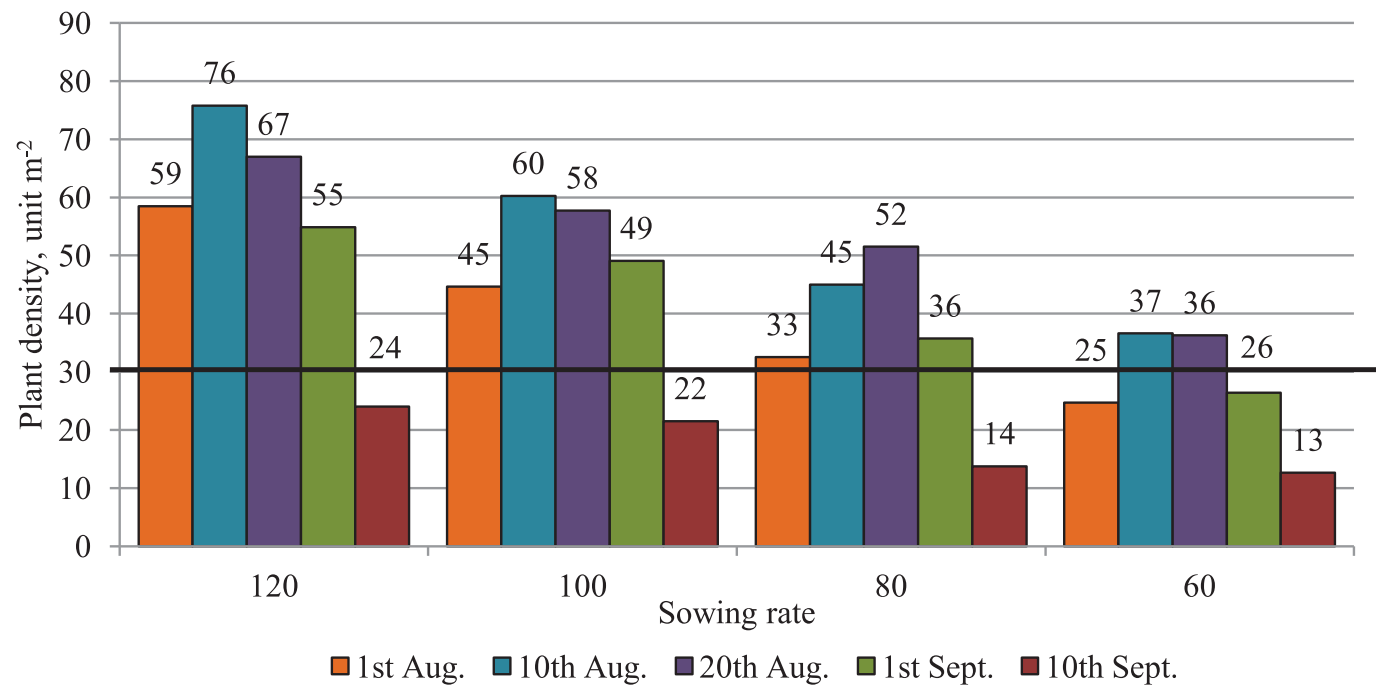

Figure 7. The influence of winter oilseed rape 'Californium' sowing date and sowing rate on plant density at harvest, $2008-2011$, (30 plants per $\mathrm{m}^{2}$ marked with a black line).

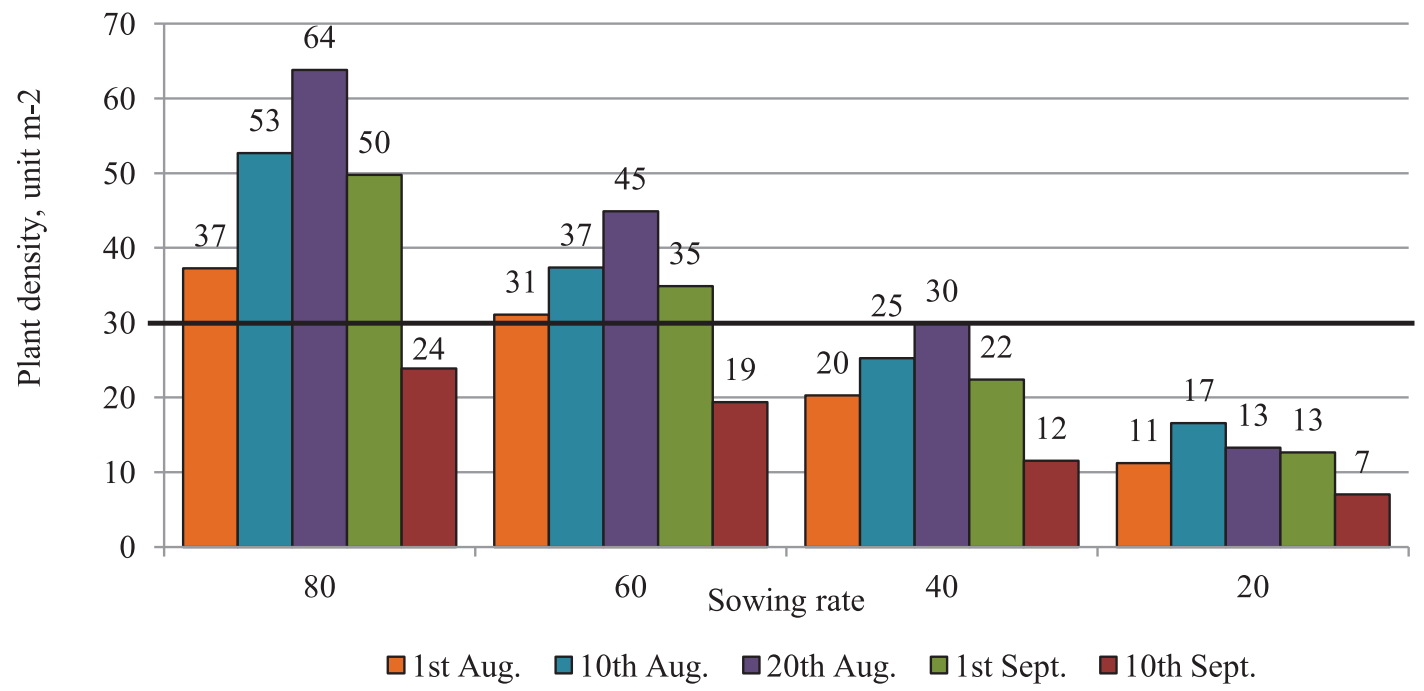

Figure 8. The influence of winter oilseed rape 'Excalibur' sowing date and sowing rate on plant density at harvest, 2008 - 2011, (30 plants per $\mathrm{m}^{2}$ marked with a black line).

per $\mathrm{m}^{2}$ at harvest were noted on 10 August sown oilseed rape (Figure 8).

In England, even if plant density was high (120 plants per $\mathrm{m}^{2}$ ) and overwintering $20 \%$, still plant number was satisfactory (24 plants per $\mathrm{m}^{2}$ ) for reasonable seed yield (Leach et al., 1999). Still 35 to 60 oilseed rape plants per $\mathrm{m}^{2}$ yielded the most in Czech Republic (Šimka et al., 2011). However, in Estonia 100 up to 150 germinate able seed per $\mathrm{m}^{2}$ are acceptable for good yields because of worse plant overwintering (Laaniste et al., 2007). In previous reportings in Middle Lithuania it was enough to have $60-80$ plants per $\mathrm{m}^{2}$ in autumn and twice less in spring $\left(30-40\right.$ plants per $\left.\mathrm{m}^{2}\right)$ when it is sown on the first decade of August (Velicka, 2003); however, a decade later plant density around 40 plants per $\mathrm{m}^{2}$ still are enough for good yields, but authors highlight the importance of sowing date (Velicka et al., 2012). Sowing date on 10 September was inappropriate for winter oilseed rape sowing because of insufficient plant establishment for acceptable average plant density at harvest time (plants not 
Relation between the sowing rate and the total number of lost plants at four sowing dates, years 2008 - 2011 (at 95\% probability level).

\begin{tabular}{lcc}
\hline \multirow{2}{*}{ Sowing date } & \multicolumn{2}{c}{ Sowing rate } \\
\cline { 2 - 3 } & 'Californium' & 'Excalibur' \\
\hline 1 August & not significant & $\mathrm{y}=0.639 \mathrm{x}-7.25$ \\
& & $\mathrm{r}=0.639 ; \mathrm{R}^{2}=0.409$ \\
\hline 10 August & $\mathrm{y}=0.269 \mathrm{x}+8.331$ & $\mathrm{y}=0.433 \mathrm{x}-3.969$ \\
& $\mathrm{r}=0.619 ; \mathrm{R}^{2}=0.383$ & $\mathrm{r}=0.674 ; \mathrm{R}^{2}=0.454$ \\
\hline 20 August & $\mathrm{y}=0.35 \mathrm{x}-15.438$ & $\mathrm{y}=0.2791 \mathrm{x}-2.469$ \\
& $\mathrm{r}=0.737 ; \mathrm{R}^{2}=0.543$ & $\mathrm{r}=0.639 ; \mathrm{R}^{2}=0.374$ \\
\hline 1 September & not significant & not significant \\
\hline
\end{tabular}

overwintered during winter 2010/2011 for both varieties).

Still, there are no fixed optimal sowing rates in Latvia's conditions. It is obvious that plant survival during the whole growing period of winter oilseed rape is different depending on sowing date and sowing rate. A moderate strong linear relation has been established between the sowing rate and the total number of lost plants for 'Californium' on two sowing dates (10 August and 20 August), and for 'Excalibur' on all plots sown in August (1August, 10 August and 20 August) (Table 2).

As the second 10 days of August is the most popular sowing period for winter oilseed rape in Latvia, results of plant density performance during growing period has to be investigated continuously. It is evident that at higher sowing rate plant loss during growing and wintering period is higher than at lower rates (Table 2). Plant density results have to be analysed combined with oilseed rape yield and plant ability to compensate the lost plants with other structural elements of yield.

\section{Conclusions}

1. Our research results confirmed that winter oilseed rape field germination was mainly affected by sowing date, also by soil moisture and productive precipitation. On four - year average, field germination was observed from $66 \%$ (on 1 September) to 95\% (on 10 August) on average for two varieties.

2. Wintering results were affected by meteorological conditions during winter. Wintering for 'Excalibur' (hybrid) was higher compared to 'Californium' (line). The worst wintering was noted in latest sowings (10 September) for both varieties. A strong tendency that plant wintering decreases by increasing sowing rate was noted for 'Excalibur'.

3. Winter oilseed rape plant wintering was not significantly $(p>0.05)$ influenced by fungicide as growth regulator application in autumn in any trial year. The tendency was observed that fungicide application affects plant survival in plots with greater density.

4. The tendency was noted that average plant density more decreased in crops sown in early August and September. It was found that influence of sowing date and sowing rate on the total plant density at harvest time was significant in all trial years $(p<0.05)$ for both cultivars. At higher sowing rate the plant loss during growing period was higher than at lower rates.

\section{References}

1. Balodis, O., Gaile, Z., Bankina, B., Vītola, R. (2007). Fungicide application effect on yield and quality formation of winter oil-seed rape (Brassica napus L.). In: Proceedings Annual $13^{\text {th }}$ International Scientific Conference "Research for Rural Development 2007", Latvia University of Agriculture, 14 - 21.

2. Balodis, O., Gaile, Z., Bankina, B. (2008). Performance of winter oilseed rape depending on some risk factors: winterhardiness and disease incidence. Proceedings of $5^{\text {th }}$ UEAA General Assembly and Associated Workshop, Riga, Latvia, 46 - 54.

3. Balodis, O., Gaile, Z., (2011). Winter oilseed rape (Brassica napus L.) autumn growth. In: Proceedings Annual $17^{\text {th }}$ International Scientific Conference "Research for Rural Development 2011", Latvia University of Agriculture, 1, 6-13. 
4. Butkute, B., Sidlauskas, G., Brazauskiene, I. (2006). Seed Yield and Quality of Winter Oilseed Rape as Affected by Nitrogen Rates, Sowing Time, and Fungicide Application. Communications in Soil Science and Plant Analysis, 37, 2725 - 2744.

5. Diepenbrock, W. (2000). Yield analysis of winter oilseed rape (Brasica napus L.): a review. Field Crops Research, 67, $35-49$.

6. Gaveliene, V., Novickiene, L., Brazauskiene, I., Miluviene, L., Kazlauskiene, D. (2005). Possibilities to use growth regulators in winter oilseed rape growing technology. 2. Effects of auxin analogues on the formation of oilseed rape generative organs and plant winter hardiness. Agronomy Research, 2 (1), 9 - 19.

7. Good, A. G.and Maclagan, J. L. (1993). Effects of drought stress on the water relations in Brassica species. Canadian Journal of Plant Science, 73, 525 - 529.

8. Laaniste, P., Joudu, J., Eremeev, V., Maeorg, E. (2007). Sowing date influence on winter oilseed rape overwintering in Estonia. Acta Agriculturae Scandinavica, Section B-Soil and Plant Science, $57,324-348$.

9. Laaniste, P., Joudu, J., Eremeev, V., Maeorg, E. (2008). Effect of sowing date and increase sowing rates on plant density and yield of winter oilseed rape (Brassica napus L.) under Nordic climate conditions. Acta Agriculturae Scandinavica, Section B-Soil and Plant Science, 58, $330-335$.

10. Leach, J. E., Stevenson, H. J., Rainbow, A. J., Mullen, L. A. (1999). Effects of high plant populations on the growth and yield of winter oilseed rape (Brassica napus). Journal of Agricultural Science, 132, 173 - 180.

11. Kondra, Z. P., Campbell, D. C., King, J. R. (1983). Temperature effects on germination of rapeseed (Brassica napus L. and B. campestris L.). Canadian Journal of Plant Science, 63, $1063-1065$.
12. Morrison, M. J., Andrews, C. J. (1992). Variable increases in cold hardiness induced in winter rape by plant growth regulators. Journal of Plant Growth Regulation, 11, $113-117$.

13. Šimka, J., Becka, D., Cihlar, P., Miknik, V., Zukalova, H., Vanak, J. (2011). Autumnal growth regulation and nitrogen fertilization on winter rapeseed (Brassica napus L convar. napus f. biennis) with different density of growth. In: Proceedings $13^{\text {th }}$ Rapessed Congress Prague, Czech Republic, June 5 - 9, 2011, 50 - 54. CD.

14. Rapacz, M. (1998). The effects of day and night temperatures during early growth of winter oilseed rape (Brassica napus L. var. oleifera cv. Gorezanski) seedlings on their morphology and cold acclimation responses. Acta Physiologiae Plantarum, 20(10), 67 - 72.

15. Rapacz, M. and Janowiak, F. (1998). Physiological Effects of winter rape (Brassica napus var. oleifera) preharedening to frost. I. Frost resistance and photosynthesis during cold acclimation. Journal Agronomy \& Crop Science, 181, 13 - 20.

16. Waalen, W. M., Tanino, K. K., Olsen, J. E., Eltun, R., Ragnli, O. A., Gusta, L. V. (2011). Freezing tolerance of winter canola cultivars is best revealed by a prolonged freeze test. Crop Science, 51(5), 1988 - 1996.

17. Velicka, R. (2003). Rape. Summary of the monograph, presented for habilitation confererence. Kaunas. 74.

18. Velicka, R., Pupaliene, R., Butkeviciene, L. M., Kriauciuniene, Z. (2012). Peculiarities of overwintering of hybrid and conventional cultivars of winter rapeseed depending on the sowing date. Acta Scientiarum Polonorum, Agricultura, 11(1), 53 - 66.

19. Velicka, R., Rimkeviciene, M., Marcinkeviciene, A., Raudonius, S. (2005). Chemical composition of crown bud and rape wintering in crop of different density. Latvia University of Agriculture, Proceedings, 13(308), 46 - 54. 